\title{
Biosintesis dan Karakterisasi Selulosa Bakteri menggunakan Media Sari Pedada (Sonneratia caseolaris) dan Kundur (Benincasa hispida)
}

\author{
Dian Fitriarni*, Irianto Sastro Prawiro, Nenengsih Verawati, Wedi Hardiansyah, Dwi Aprianti \\ Teknologi Pertanian Politeknik Negeri Ketapang, Kalimantan Barat
}

Diterima : 05 Desember 2018, Revisi akhir : 08 April 2019, Disetujui terbit : 26 Juni 2019

Biosynthesis and Characterization of Bacterial Cellulose

using Fruit Extract Media from Pedada (Sonneratia caseolaris) and Kundur (Benincasa hispida)

\begin{abstract}
Bacterial cellulose is a product that has been widely applied in the medical, food, and even alternative raw materials for replacing several types of products made from plant cellulose. Many factors influence the quality of bacterial cellulose produced such as raw materials and nitrogen sources for fermentation media. This study aims to determine the characteristics of bacterial cellulose from fermentation using two different media of pedada juice and pedada with various nitrogen sources. Kundur fruit juice and pedada fruit juice have different characteristics so that affect the formulation of the ingredients used. The two media used were modified by adding various nitrogen sources to see how the characteristics of bacterial cellulose produced. The research was carried out through experimental stages to obtain the suitable formulation to produce maximum cellulose thickness. Based on the characterization result of bacterial cellulose, the dry weight obtained from the use of pedada fruit juice media using urea, yeast, green bean was in the amount of $0.37 \mathrm{~g} / \mathrm{L}, 0.52 \mathrm{~g} / \mathrm{L}$, and $2.23 \mathrm{~g} / \mathrm{L}$, respectively. On the other hand bacterial cellulose produced from the use of kundur fruit juice media with the same nitrogen source was obtained with the dry weight of $1.38 \mathrm{~g} / \mathrm{L}, 0.32 \mathrm{~g} / \mathrm{L}$, and $5.43 \mathrm{~g} / \mathrm{L}$, respectively.
\end{abstract}

Keywords: bacterial cellulose, pedada, kundur, yeast, green bean

\begin{abstract}
Abstrak
Selulosa bakteri merupakan satu produk yang telah banyak diaplikasikan pada bidang medis, pangan, dan bahkan dapat menjadi bahan baku alternatif untuk mengganti beberapa jenis produk berbahan baku selulosa tumbuhan. Banyak faktor yang berpengaruh terhadap kualitas selulosa bakteri yang dihasilkan seperti bahan baku dan sumber nitrogen untuk media fermentasi. Penelitian ini bertujuan untuk mengetahui karakteristik selulosa bakteri dari hasil fermentasi menggunakan dua media dari sari buah pedada dan kundur dengan berbagai sumber nitrogen berbeda. Sari buah kundur dan sari buah pedada memiliki karakteristik berbeda sehingga mempengaruhi formulasi bahan yang digunakan. Kedua media yang digunakan dimodifikasi dengan penambahan berbagai sumber nitrogen untuk melihat bagaimana karakteristik selulosa bakteri yang dihasilkan. Penelitian dilakukan melalui tahapan eksperimen untuk mendapatkan formulasi yang tepat agar diperoleh ketebalan selulosa maksimal. Berdasarkan hasil karakterisasi selulosa bakteri, berat kering selulosa yang dihasilkan menggunakan media sari buah pedada dengan penambahan urea, yeast, ekstrak kecambah kacang hijau berturut turut $0,37 \mathrm{~g} / \mathrm{L}, 0,52 \mathrm{~g} / \mathrm{L}$, dan 2,23 g/L, sedangkan selulosa yang dihasilkan menggunakan media sari buah kundur dengan penambahan urea, yeast, ekstrak kecambah kacang hijau berturut turut $1,3 \mathrm{~g} / \mathrm{L}, 0,32 \mathrm{~g} / \mathrm{L}$, dan $5,43 \mathrm{~g} / \mathrm{L}$.
\end{abstract}

Kata kunci : selulosa bakteri, pedada, kundur, yeast, kacang hijau 


\section{Pendahuluan}

Selulosa adalah salah satuanggota makromolekul yang berlimpah di bumi. Secara umum, diketahui bahwa selulosa adalah salah satu komponen utama pada dinding sel tanaman. Namun demikian, selulosa dapat disintesis oleh organisme lain selain tanaman, seperti bakteri, fungi, dan alga.

Selulosa bakteri adalah biopolimer yang diproduksi oleh beberapa bakteri. Selulosa bakteri memiliki rumus molekul sama dengan selulosa tanaman, yaitu $\left(\mathrm{C}_{6} \mathrm{H}_{10} \mathrm{O}_{5}\right)_{\mathrm{n}}$, akan tetapi ciri fisik dan kimia keduanya berbeda. Selulosa yang dihasilkan dari mikroorganisme memiliki persamaan rumus molekul dengan tanaman (Donini et al., 2010). Selulosa bakteri diproduksi oleh kelompok bakteri asam asetat dalam medium sintetik maupun non sintetik melalui proses fermentasi (Esa, Tasirin and Rahman, 2014). Selulosa bakteri umumnya diproduksi oleh kelompok bakteri genus Acetobacter yang saat ini dikenal dengan nama Glucanacetobacter xylinum (sebelum dikenal dengan nama Acetobacter xylinum). Selain dari Acetobacter sp., selulosa bakteri juga bisa diproduksi oleh beberapa mikroorganisme lain seperti spesies Agrobacterium tumefaciens, Gluconacetobacter sp., Rhizobium spp., dan Sarcina ventriculli (Moniri et al., 2017).

Aplikasi selulosa bakteri sangat luas di banyak industri, seperti di industri biomedis, produksi kertas, industri makanan, dan kosmetik. Yang et al., (2012) dan Yang et al., (2009) melaporkan bahwa selulosa bakteri dengan penambahan Cadmium selenide (CdSe) nanocomposite menunjukkan sifat pholuminescent, sifat thermal dan mekanik yang baik. Produk berbahan baku selulosa bakteri ini diaplikasikan sebagai membran pertukaran proton (PEM) pada sel bahan bakar yang dapat meminimalisasi polusi. Barud et al., (2008) mengembangkan selulosa bakteri berbasis nanokomposit dengan perak trietanolamina (TEA) untuk anti mikroba yang dimanfaatkan untuk pembungkus luka. Dobre et al. (2012) mengembangkan selulosa bakteri berbasis nanokomposit dengan penambahan asam sorbat yang dimodifikasi dengan PVA untuk bahan kemasan bahan makanan antimikroba.

Ada banyak metode yang dilakukan untuk memproduksi selulosa bakteri. Metode yang dilakukan dapat berupa modifikasi pada media hingga pada modifikasi pada teknik fermentasi yang digunakan. Modifikasi pada jenis media fermentasi untuk produksi selulosa bakteri telah banyak berkembang. Tidak hanya air kelapa, saat ini telah banyak dilaporkan juga penggunaan bahan dasar media kultur lainnya seperti teh (Neera, Ramana and Batra, 2015), media jus buah (Kosseva et al., 2017), limbah buah (Tsouko et al., 2015), jerami gandum (Chen et al., 2013).

Pada penelitian ini digunakan sari buah kundur dan sari buah pedada untuk media kultur fermentasi produksi selulosa bakteri. Buah pedada merupakan buah yang banyak ditemukan di daerah sekitar pesisir pantai. Oleh penduduk sekitar, terutama di daerah Ketapang, Kalimantan Barat, tanaman ini hampir tidak dilirik dan dimanfaatkan secara maksimal. Disisi lain, buah kundur merupakan buah dari tanaman herba yang mudah dibudidayakan namun sangat minim dalam pemanfaatan dan pengembangannya menjadi produk bernilai tambah. Kedua buah dari tanaman ini memiliki potensi untuk dieksplorasi potensinya menjadi media dasar dalam pembuatan selulosa dari bakteri. Pengembangan dan pemanfaatan selulosa bakteri ini merupakan dasar untuk membuat produk selulosa yang nantinya dapat dimanfaatkan dalam bidang pangan dan kesehatan. Pemilihan bahan untuk produksi selulosa bakteri harus memiliki sumber karbon dan sumber nitrogen. Bahan sebagai sumber nitrogen yang digunakan dalam penelitian ini meliputi urea, yeast, dan ekstrak kecambah kacang hijau. Produk yang dihasilkan nantinya akan dianalisis karakteristiknya melalui parameter ketebalan, kadar air, kadar abu, kadar serat selulosa dan berat selulosa yang dihasilkan.

\section{Bahan dan Metode}

Buah pedada dan buah kundur yang digunakan diperoleh dari Kecamatan Benua Kayong, Kabupaten Ketapang, Kalimantan Barat. Proses pembuatan selulosa bakteri dilakukan berdasarkan metode Djajati, Sarofa and Syamsul, (2018) dan Majesty et al., (2015) dengan modifikasi yang cara kerjanya sebagai berikut:

\section{Pembuatan Ekstrak Daging Buah Pedada}

Buah pedada yang digunakan dalam penelitian ini adalah sebanyak $1,9 \mathrm{~kg}$, buah pedada yang dipilih adalah buah yang tidak terlalu tua dan tidak terlalu muda. Buah terpilih dikupas, dipotong-potong kecil, dan ditimbang. Setelah ditimbang buah dicuci bersih kemudian 
dihancurkan menggunakan blender. Hasil berupa bubur daging buah pedada kemudian diperas dan disaring untuk mendapatkan ekstrak daging buah daging buah pedada. Ekstrak buah pedada kemudian diambil sebanyak $3000 \mathrm{~mL}$.

\section{Pembuatan Ekstrak Daging Buah Kundur}

Buah kundur yang dipilih adalah buah tidak terlalu tua dan tidak terlalu muda. Buah kundur terpilih dikupas, dipotong-potong kecil, ditimbang. Setelah ditimbang buah dicuci bersih dan dihancurkan dengan menggunakan blender. Hasil berupa bubur buah kundur yang kemudian disaring untuk mendapatkan sari buah kundur.

\section{Pembuatan Ekstrak Kecambah Kacang Hijau}

Kecambah segar sebanyak $300 \mathrm{~g}$ diblender untuk mendapatkan bubur kecambah kemudian ditambahkan $600 \mathrm{~mL}$ air dan diaduk hingga rata. Campuran bahan kemudian direbus hingga mendidih. Hasil perebusan disaring untuk mendapatkan ekstrak kecambah yang akan digunakan untuk pembuatan selulosa bakteri.

\section{Pembuatan Media Fermentasi}

Pembuatan media fermentasi dilakukan mengacu pada Djajati, et al, (2008) dan Tahir, et al, (2008) dengan modifikasi. Sementara itu, pembuatan media fermentasi menggunakan sari buah kundur mengacu pada Tahir, (2008); Setyaningtyas, (2014); (Fifendy and Annisah, 2012) dengan modifikasi. Starter bakteri $A$. xylinum diperoleh dari LaboratoriumMikrobiologi Jurusan Teknologi Pertanian, Politeknik Negeri Ketapang. Formulasi pembuatan selulosa bakteri disajikan pada Tabel 1. Karakterisasi selulosa bakteri dilakukan dengan parameter uji rendemen, ketebalan, kadar air (Horwitz and Latimer, 2010), kadar abu (Sudarmadji, 1989), kadar serat (SNI 01-2891-1992) dan berat selulosa berdasarkan berat basah dan berat kering menggunakan metode gravimetrik.

\section{Hasil dan Pembahasan}

Berdasarkan hasil eksperimen diperoleh formulasi media untuk sintesis selulosa bakteri menggunakan media sari buah pedada dan sari buah kundur (Tabel 1). Formulasi bahan yang digunakan berbeda pada volume asam asetat
Tabel 1. Formulasi Bahan Media Sintesis Selulosa Bakteri menggunakan Media Sari Buah Pedada dan Sari Buah Kundur

\begin{tabular}{lcc}
\hline Bahan & $\begin{array}{c}\text { Media Sari } \\
\text { Buah Pedada }\end{array}$ & $\begin{array}{c}\text { Media Sari } \\
\text { Buah Kundur }\end{array}$ \\
\hline Jus buah (buah : air & $1000 \mathrm{~mL}$ & $1000 \mathrm{~mL}$ \\
$=1: 1)$ & & \\
Urea & $3 \mathrm{~g}$ & $3 \mathrm{~g}$ \\
Yeast & $3 \mathrm{~g}$ & $3 \mathrm{~g}$ \\
Ekstrak kecambah & $300 \mathrm{~mL}$ & $300 \mathrm{~mL}$ \\
kacang hijau & & \\
Gula & $90 \mathrm{~g}$ & $90 \mathrm{~g}$ \\
Asam asetat & $10 \mathrm{~mL}$ & $200 \mathrm{~mL}$ \\
\hline
\end{tabular}

yang ditambahkan. Pada media sari buah kundur ditambahkan $200 \mathrm{~mL}$ asam asetat agar media dapat mencapai nilai $\mathrm{pH} 4$ untuk mendukung pertumbuhan bakteri A. xylinum.

Asam asetat pada pembuatan selulosa bakteri, berfungsi sebagai penurun $\mathrm{pH}$ medium. Nilai $\mathrm{pH}$ medium dalam pembuatan selulosa bakteri harus sesuai dengan kondisi ideal pertumbuhan A. xylinum, yaitu berkisar 3,5-4. Proses pembentukan selulosa bakteri dapat berjalan maksimal dengan mengkondisikan $\mathrm{pH}$ medium sesuai dengan syarat pertumbuhan A. xylinum.. Arviyanti and Yulimartani (2009) menyatakan bahwa $A$. xylinum mendapatkan nutrisi yang cukup untuk pertumbuhan pada $\mathrm{pH} 4$ dan dapat tumbuh unggul dibanding bakteri pembusuk yang mengganggu pertumbuhan selulosa bakteri.

Pengamatan masa inkubasi selulosa bakteri didasarkan pada pengamatan secara langsung pada hari 3, 5, dan 7. Berdasarkan hasil pengamatan diperoleh data bahwa penggunaan sumber nitrogen dari urea, yeast, dan ekstrak kecambah kacang hijau memberikan pengaruh pada masa inkubasi pembentukan selulosa bakteri dan karakteristik selulosa bakteri yang dihasilkan. Secara umum, dengan lama waktu pengamatan selama 10 hari diperoleh masa inkubasi terpendek terbentuknya serat halus terlihat pada hari ke-3 dan hari ke-5, yaitu dengan penggunaan yeast dan ekstrak kecambah kacang hijau, sedangkan dengan menggunakan urea, selulosa bakteri terbentuk pada hari ke 7. Perbedaan masa inkubasi kemungkinan disebabkan karena perbedaan bahan. Bahan seperti yeast dan ekstrak kecambah kacang hijau merupakan bahan baku alami sebagai sumber nitrogen sehingga dimungkinkan proses adaptasi oleh mikroba cenderung lebih 
cepat jika dibandingkan dengan urea. Secara teoritis, proses pembentukan selulosa bakteri diawali dengan terjadinya penjernihan medium pada hari 2-3 (perlakuan yeast dan ekstrak kecambah kacang hijau) dan pada hari ke 5 (perlakuan urea). Pada hari berikutnya mulai terlihat adanya pembentukkan lapisan tipis seperti benang-benang halus. Lapisan ini yang merupakan lapisan awal pembentukan selulosa bakteri. Pada hari berikutnya lapisan ini semakin terlihat tebal (tetapi tidak merata) dan mengapung ke atas permukaan media.

Selulosa bakteri merupakan produk hasil fermentasi yang menyerupai gel dan tampak terapung dalam medium. Selulosa bakteri tampak sebagai suatu massa fibril tidak beraturan yang menyerupai benang atau kapas apabila dilihat di bawah mikroskop bertekstur agak kenyal, sangat padat, berwarna putih hingga sedikit transparan. Hasil fermentasi berupa produk selulosa bakteri diambil pada hari ke 10. Produk yang diperoleh kemudian dianalisis kadar air, kadar abu, kadar serat selulosa bakteri, dan berat selulosa sebelum dan sesudah dikeringkan.

\section{Rendemen}

Berdasarkan Tabel 2 dan Tabel 3 nilai rendemen terbesar terdapat pada penggunaan media sari buah kundur dengan perlakuan yeast, yaitu sebesar $18,89 \%$, sedangkan pada selulosa bakteri hasil fermentasi menggunakan media sari buah pedada diperoleh rendemen tertinggi dari perlakuan penambahan ekstrak kecambah kacang hijau, yaitu sebesar 12,16\%. Hal ini dapat terjadi karena perbedaan karakteristik sari buah pedada dan sari buah kundur. Kedua sari buah berbeda dalam hal nilai $\mathrm{pH}$, kandungan karbohidrat, protein, dan mineral. Kandungan nutrisi sari buah sebagai media dasar dapat mempengaruhi rendemen selulosa bakteri yang dihasilkan karena merupakan faktor utama yang menjadi sumber pasokan nutrisi untuk pertumbuhan dan aktivitas bakteri pembentuk selulosa.

Tabel 2. Hasil Analisis Selulosa Bakteri menggunakan Media Sari Buah Pedada dengan Tiga Perlakuan Penambahan Sumber Nitrogen

\begin{tabular}{|c|c|c|c|c|}
\hline \multirow[b]{2}{*}{ Hasil Pengamatan } & \multicolumn{3}{|c|}{ Sumber Nitrogen } & \multirow{2}{*}{$\begin{array}{c}\text { Standar } \\
\text { SNI 01-4317-1996 }\end{array}$} \\
\hline & Urea & Yeast & $\begin{array}{c}\text { Ekstrak Kecambah } \\
\text { Kacang Hijau }\end{array}$ & \\
\hline Rendemen & $6,63 \%$ & $9,73 \%$ & $12,16 \%$ & - \\
\hline Ketebalan & $0,2 \mathrm{~cm}$ & $0,9 \mathrm{~cm}$ & $1,3 \mathrm{~cm}$ & - \\
\hline Kadar air & $86,96 \%$ & $96,72 \%$ & $98,01 \%$ & - \\
\hline Kadar abu & $0,24 \%$ & $0,38 \%$ & $0,44 \%$ & - \\
\hline Kadar serat & $2,53 \%$ & $2,42 \%$ & $11,62 \%$ & $4,5 \%$ \\
\hline Berat awal & $27,60 \mathrm{~g}$ & $32,81 \mathrm{~g}$ & $37,72 \mathrm{~g}$ & \\
\hline Berat kering & $0,37 \mathrm{~g} / \mathrm{L}$ & $0,52 \mathrm{~g} / \mathrm{L}$ & $2,23 \mathrm{~g} / \mathrm{L}$ & \\
\hline
\end{tabular}

Tabel 3. Hasil Analisis Selulosa Bakteri menggunakan Buah Kundur dengan Tiga Perlakuan Penambahan Sumber Nitrogen

\begin{tabular}{|c|c|c|c|c|}
\hline \multirow[b]{2}{*}{ Hasil Pengamatan } & \multicolumn{3}{|c|}{ Sumber Nitrogen } & \multirow{2}{*}{$\begin{array}{c}\text { Standar } \\
\text { SNI 01-4317-1996 }\end{array}$} \\
\hline & Urea & Yeast & $\begin{array}{l}\text { Ekstrak Kecambah } \\
\text { Kacang Hijau }\end{array}$ & \\
\hline Rendemen & $0,04 \%$ & $26,06 \%$ & $18,89 \%$ & - \\
\hline Ketebalan & $0,3 \mathrm{~cm}$ & $1,5 \mathrm{~cm}$ & $1,2 \mathrm{~cm}$ & - \\
\hline Kadar air & $96,66 \%$ & $96,06 \%$ & $97,11 \%$ & - \\
\hline Kadar abu & $0,31 \%$ & $0,19 \%$ & $0,13 \%$ & - \\
\hline Kadar serat & $5,68 \%$ & $2,87 \%$ & $30,92 \%$ & $4,5 \%$ \\
\hline Berat awal & $27,55 \mathrm{~g}$ & $39,87 \mathrm{~g}$ & $35,05 \mathrm{~g}$ & \\
\hline Berat kering & $1,38 \mathrm{~g} / \mathrm{L}$ & $0,32 \mathrm{~g} / \mathrm{L}$ & $5,43 \mathrm{~g} / \mathrm{L}$ & \\
\hline
\end{tabular}


Rendemen selulosa bakteri merupakan persentasi berat basah selulosa bakteri yang dapat diketahui melalui perbandingan berat selulosa bakteri yang dihasilkan dengan volume media awal. Melalui data persentase rendemen dapat diketahui besar biomassa selulosa bakteri yang dihasilkan dari fermentasi media menggunakan bakteri A. xylinum. Persentase nilai rendemen yang rendah cenderung menunjukkan bahwa proses fermentasi tidak berlangsung maksimal. Proses fermentasi dapat berlangsung maksimal karena dipengaruhi oleh komposisi bahan, variasi substrat, waktu fermentasi dan aktivitas bakteri pembentuk selulosa.

Hasil rendemen dapat dipengaruhi oleh jenis sumber nutrisi dan keasaman medium selulosa bakteri seperti halnya pada ketebalan. Tinggi rendahnya rendemen selulosa bakteri yang dihasilkan bergantung pada tebal dan $\mathrm{pH}$. SurmaŚlusarska, Presler and Danielewicz, (2008) menyatakan bahwa rendemen sebagai hasil dari proses biosintesis tergantung pada banyak faktor yaitu suhu, waktu, dan luasnya permukaan dengan volume media. Luas permukaan dan volume media menentukan luasnya penyebaran oksigen dalam media. Molina-Ramírez et al., (2017) menyatakan bahwa glukosa dan fruktosa berperan sebagai sumber karbon dan energi dikombinasikan dengan penambahan asam asetat untuk menjaga $\mathrm{pH}$, serta kadar oksigen terlarut yang tepat, akan menghasilkan rendemen selulosa yang sangat baik. Costa et al., (2017) menyatakan bahwa semakin tebal selulosa bakteri maka semakin berat hasil selulosa bakteri oleh karena itu semakin besar pula hasil rendemen yang diperoleh. Perbedaan nilai rendemen dipengaruhi oleh ketebalan selulosa bakteri, dimana semakin tebal selulosa bakteri maka rendemennya juga semakin tinggi dan ketersediaan oksigen dalam medium lebih banyak dibandingkan dengan penambahan konsentrasi yang lain, dimana oksigen sangat dibutuhkan oleh A. xylinum dalam proses metabolisme dan pembentukan partikel selulosa bakteri). Wijayanti, Kumalaningsih and Effendi, (2012) menyatakan bahwa semakin tinggi $\mathrm{pH}$ maka semakin tinggi pula rendemen yang dihasilkan.

\section{Ketebalan Selulosa Bakteri}

Berdasarkan hasil pengukuran, ketebalan selulosa bakteri tertinggi diperoleh dari selulosa bakteri dengan perlakuan penambahan ekstrak kecambah kacang hijau $(1,3 \mathrm{~cm})$ diikuti penambahan yeast $(0,9 \mathrm{~cm})$ dan yang terendah diperoleh dari selulosa bakteri dengan perlakuan penambahan urea $(0,2 \mathrm{~cm})$. Perbedaan ketebalan dipengaruhi oleh sumber nutrisi yang digunakan. Nutrisi yang tersedia dalam medium ekstrak buah pedada untuk pertumbuhan $A$. xylinum. Nutrisi yang harus dipenuhi adalah ketersediaan sumber karbon sebagai sumber energi dan sumber nitrogen. Berdasarkan jenis sumber nitrogen yang digunakan didapatkan ekstrak kecambah kacang hijau memiliki pengaruh yang nyata terhadap ketebalan selulosa bakteri. Ekstrak kecambah kacang hijau berpotensi untuk menjadi salah satu sumber nitrogen alami dalam proses pembuatan selulosa bakteri. Hal ini dapat dikarenakan ekstrak kecambah kacang hijau menyediakan kandungan protein yang dibutuhkan dalam proses fermentasi selulosa bakteri. Mumbarkar and Shravya, (2013) melaporkan bahwa kecambah kacang hijau memiliki kandungan protein $1 \mathrm{mg} / \mathrm{ml}$. sehingga cocok untuk dijadikan sebagai alternatif sumber nitrogen yang dibutuhkan untuk pertumbuhan bakteri A. xylinum.

Hastuti et al., (2017) melaporkan bahwa penambahan ekstrak kecambah kacang hijau mempengaruhi ketebalan selulosa bakteri berbahan dasar media buah lerry. Ketebalan nata optimum diperoleh dari penambahan 100\% ekstrak kecambah kacang hijau. Faktorfaktor lain yang dapat mempengaruhi ketebalan selulosa bakteri adalah konsentrasi sukrosa, sumber nitrogen, luas permukaan fermentasi, dan lama proses fermentasi. Ketebalan selulosa bakteri pada umumnya akan terus bertambah sampai medium habis terfermentasi. Semakin luas dan dangkal wadah medium fermentasi, semakin sempit wadah maka selulosa bakteri yang terbentuk akan semakin tebal karena suplai oksigen pada wadah lebih banyak. Produksi selulosa bakteri meningkat dengan meningkatkan luas permukaan dan kedalaman media (ALKalifawi and Hassan, 2014).

\section{Kadar Air}

Berdasarkan hasil analisis kadar air, diperoleh nilai persentase berkisar $86,96 \%$ hingga $98,01 \%$. Nilai kadar air terendah didapat dari perlakuan urea, yaitu $86,96 \%$, diikuti oleh penambahan yeast, yaitu sebesar $96,72 \%$. Sementara itu, nilai kadar air yang tertinggi dari penambahan ekstrak kacang hijau, yaitu sebesar 98,01\%. 
Berdasarkan SNI, kadar air selulosa bakteri tidak dicantumkan, tetapi berdasarkan Rebelo et al., (2018), selulosa bakteri dapat memiliki kandungan air hingga 98\%. Air yang terkandung dalam selulosa bakteri terdiri dari air terikat 30\% dan air bebas $89,7 \%$. Adanya kadar air pada selulosa bakteri karena kemampuannya dalam mengabsorsi air hingga 98\%. Secara fisik selulosa bakteri memiliki fitur selulosa yang kuat.

Kadar air selulosa bakteri mempengaruhi elastisitas selulosa. Pengeringan selulosa bakteri akan mengakibatkan dehidrasi selulosa, jarak antar serat-serat penyusun selulosa menjadi lebih rapat, terjadi peningkatan kekerasan (kekakuan) membran menjadi lebih kompak dan kohesif. Air dalam selulosa bakteri tersimpan dalam serat selulosa yang berbentuk kapiler. Ketika air teruapkan, maka terjadi perubahan bentuk baik tekstur maupun volume selulosa.

Indrianingsih et al., (2017) menyatakan bahwa selulosa bakteri mempunyai kapasitas penyerapan air yang lebih besar dibandingkan dengan selulosa tanaman. Hal ini dikarenakan, pada selulosa bakteri terdapat ikatan hidrogen yang lebih kuat dengan rantai polimer selulosa lebih panjang. Hasil analisis kadar air dapat memberikan informasi tentang kemampuan daya serap selulosa bakteri yang dapat dimanfaatkan untuk aplikasi pada bidang pengobatan dan pengawetan makanan.

\section{Kadar Abu}

Berdasarkan hasil analisis kadar abu, selulosa bakteri yang diperoleh adalah berkisar 0,24\% sampai $0,44 \%$. Nilai kadar abu terendah didapat dari perlakuan penambahan urea yaitu $0,24 \%$ diikuti oleh penambahan yeast yaitu $0,38 \%$ dan yang tertinggi dari perlakuan penambahan ekstrak kecambah kacang hijau yaitu sebesar $0,44 \%$. Semakin tinggi kadar abu memberikan informasi tentang kandungan mineral dalam selulosa bakteri, sehingga berdasarkan hasil analisis diketahui kandungan mineral tertinggi pada selulosa bakteri terdapat pada selulosa bakteri yang dibuat dengan bahan tambahan ekstrak kacang hijau. Penentuan kadar abu berhubungan erat dengan kandungan mineral yang terdapat dalam suatu bahan (Yustinah, 2012).

\section{Kadar Serat}

Berdasarkan hasil analisis serat kasar selulosa bakteri yang diperoleh adalah berkisar 2,42\% sampai $11,62 \%$. Nilai serat kasar terendah didapat dari perlakuan penambahan yeast yaitu 2,42\% diikuti oleh perlakuan dengan penambahan urea yaitu $2,53 \%$ dan yang tertinggi dari perlakuan dengan penambahan ekstrak kecambah kacang hijau yaitu sebesar $11,62 \%$. Besar kecilnya kadar serat dipengaruhi oleh ketersediaan nutrisi dalam media yang digunakan dalam proses pembuatan selulosa bakteri.

Serat pada selulosa bakteri merupakan serat yang dihasilkan aktivitas mikrobia sebagai produk ekstraseluler yang terdiri dari rangkaian susunan mikrofibril. Mikrofibril atau pelikel ini merupakan tipe selulosa yang mempunyai struktur kimia selulosa yang juga dimiliki oleh tumbuhan. Penelitian ini menggunakan A. xylinum berkerja dengan mengubah bahan seperti gula (sukrosa atau glukosa) menjadi selulosa. Perubahan dilakukan melalui proses perombakan gula yang membentuk prekursor yang membentuk polimer-polimer glukosa menjadi selulosa dengan bantuan enzim sebagai katalisator (Çoban and Biyik, 2011).

Besar kecilnya kadar serat dipengaruhi oleh kandungan nitrogen dalam medium juga karbon organik pada media fermentasi. Semakin besar kadar nitrogen dan semakin tinggi kandungan karbon pada media berkorelasi pada semakin besar pula kadar serat dalam selulosa bakteri yang berpengaruh pada berat kering selulosa bakteri yang diperoleh. Nitrogen dan senyawa karbon organik dalam medium akan dimanfaatkan oleh A. xylinum untuk pembentukan sel-sel baru. Nitrogen digunakan untuk membantu proses sintesis protein yang dibutuhkan untuk produksi serat selulosa bakteri. Semakin banyak sel yang terbentuk akan memungkinkan pembentukan serat selulosa bakteri yang lebih banyak. Kadar serat merupakan salah satu standar baku SNI untuk produk nata (selulosa yang diproduksi oleh bakteri) dijadikan standar yang dipakai dalam penelitian ini. Analisis serat kasar dilakukan bertujuan untuk mengetahui kandungan selulosa yang dihasilkan oleh A. xylinum selama proses fermentasi. Kadar serat berhubungan dengan ketebalan dan kadar air selulosa bakteri. Semakin tebal selulosa yang dihasilkan maka dapat mengindikasikan bahwa kadar serat yang terkandung dalam selulosa juga semakin tinggi. Semakin tinggi persentase jumlah serat maka semakin tinggi persentase air yang terserap.

Struktur susunan dan formasi matriks mikrofibril selulosa bakteri sangat tergantung 
pada beberapa faktor seperti aktivitas mikroorganisme, komposisi dan kondisi media, waktu fermentasi, jumlah inokulum, dan ketersediaan sumber karbon. Perlakukan terhadap media fermentasi selama waktu penyimpanan mempengaruhi karakteristik selulosa bakteri. Karakteristik selulosa bakteri yang diperlakukan dalam kondisi statis lebih baik dibandingkan kondisi dinamis.

\section{Berat Kering Selulosa Bakteri}

Berdasarkan hasil pengukuran berat basah selulosa bakteri yang diperoleh memiliki perbedaan disetiap perlakuan. Berat selulosa terbesar didapatkan dari selulosa bakteri yang diproduksi menggunakan sari buah kundur dengan sumber nitrogen menggunakan ekstrak kecambah kacang hijau yaitu 5,43\%. Beberapa hasil penelitian terdahulu melaporkan berbagai variasi berat kering selulosa bakteri yang diperoleh. Nazeri, (2012) menggunakan limbah buah nanas dengan berbagai perlakuan suhu,dan konsentrasi medium memperoleh berat kering selulosa rata-rata antara 0,1-3,5 g. AdebayoTayo, Akintunde and Sanusi, (2017) melaporkan berat kering selulosa bakteri yang diproduksi menggunakan media sari buah nanas, semangka dan pepaya menghasilkan berat kering selulosa bakteri dengan berat rata-rata antara 0,3-6,4 g/L. Zahan, Hedzir and Mustapha (2017) melaporkan berat kering selulosa bakteri yang diproduksi menggunakan media sari buah pepaya dan $A$. xylinum menghasilkan nata dengan berat kering selulosa bakteri dengan berat rata-rata antara 3,3 $\mathrm{g} / \mathrm{L}-16,10 \mathrm{~g} / \mathrm{L}$.

Pengukuran berat selulosa dapat memberikan informasi tentang karakteristik matriks selulosa dilihat dari kemampuan daya serapnya. Berat kering digunakan sebagai tolak ukur berat murni selulosa bakteri tanpa kandungan air, beratnya relatif berbeda sesuai dengan perlakuan yang diberikan selama proses produksi. Selain itu melalui berat kering selulosa dapat diperoleh informasi tentang potensinya untuk dijadikan sebagai bahan baku pembuatan produk-produk industri.

\section{Kesimpulan}

Penelitian ini menggunakan dua jenis media berbeda, yaitu media sari buah pedada dan media sari buah kundur. Perbedaan karakteristik sari buah mempengaruhi formulasi bahan, seperti penambahan $200 \mathrm{~mL}$ volume asam asetat untuk media sari buah kundur. Selulosa bakteri dikarakteristik berdasarkan rendemen, kadar air, kadar abu, kadar serat, dan berat selulosa. Berdasarkan pada kadar serat dan berat kering selulosa, angka tertinggi diperoleh dari penggunaan media sari buah kundur dengan ekstrak kecambah kacang hijau sebagai sumber nitrogen kemudian diikuti selulosa dari sari buah pedada dengan perlakuan yang sama.

\section{Daftar Pustaka}

Adebayo-Tayo, B., Akintunde, M. and Sanusi, J. (2017) 'Effect of Different Fruit Juice Media on Bacterial Cellulose Production by Acinetobacter sp. BAN1 and Acetobacter pasteurianus PW1', Journal of Advances in Biology \& Biotechnology, 14(3), pp. 1-9. doi: $10.9734 / \mathrm{JABB} / 2017 / 34171$.

AL-Kalifawi, E. J. and Hassan, I. A. (2014) 'Factors Influence on the yield of Bacterial Cellulose of Kombucha (Khubdat Humza)', Baghdad Science Journal, 11(3), pp. 14201428. doi: 10.21123/bsj.11.3.1420-1428.

Arviyanti, E. and Yulimartani, N. (2009) Pengaruh Penambahan Air Limbah Tapioka pada Proses Pembuatan Nata. Semarang. Available at: http://eprints. undip.ac.id/3468/.

Barud, H. S. et al. (2008) 'Self-supported silver nanoparticles containing bacterial cellulose membranes', Materials Science and Engineering: $C, 28(4)$, pp. 515-518. doi: 10.1016/j.msec.2007.05.001.

Chen, L. et al. (2013) 'Biotransformation of wheat straw to bacterial cellulose and its mechanism', Bioresource Technology, 135, pp. 464-468. doi: 10.1016/j. biortech.2012.10.029.

Çoban, E.P. and Biyik, H. (2011) 'Effect of various carbon and nitrogen sources on cellulose synthesis by acetobacter lovaniensis HBB5', African Journal of Biotechnology, 10(27), pp. 5346-5354.

Costa, A. F. S. et al. (2017) 'Production of bacterial cellulose by Gluconacetobacter hansenii using corn steep liquor as nutrient sources', Frontiers in Microbiology. Frontiers Media S.A., 8(OCT). doi: 10.3389/ fmicb.2017.02027.

Djajati, S., Sarofa, U. and Syamsul, A. (2018) 'Pembuatan nata de manggo (kajian. konsentrasi sukrosa dan lama fermentasi)', Jurnal Teknologi Pangan, 3(2), pp. 113-127. doi: 10.33005/JTP.V3I2.1022. 
Dobre, L. M. et al. (2012) 'Modelling of sorbic acid diffusion through bacterial cellulosebased antimicrobial films', Chemical Papers, 66(2), pp. 144-151. doi: 10.2478/s11696011-0086-2.

Donini, Í. A. N. et al. (2010) 'Biosynthesis and recent advances in production of bacterial cellulose', Eclética Química Journal, 35(4), pp. 166-178. doi: 10.26850/1678-4618eqj. v35.4.2010.p165-178.

Esa, F., Tasirin, S. M. and Rahman, N. A. (2014) 'Overview of Bacterial Cellulose Production and Application', Agriculture and Agricultural Science Procedia, 2, pp. 113-119. doi: 10.1016/j.aaspro.2014.11.017.

Fifendy, M. and Annisah, N. (2012) 'Kualitas nata de citrullus dengan menggunakan berbagai macam starter', Jurnal Sainstek, IV(2), pp. $158-164$.

Hastuti, M. et al. (2017) Prosiding SNST. Semarang: Fakultas Teknik, Universitas Wahid Hasyim.

Horwitz, W. and Latimer, G. (eds) (2010) Official Methods of Analysis of AOAC International. 18th edn.

Indrianingsih, A. W. et al. (2017) 'Preliminary study on biosynthesis and characterization of bacteria cellulose films from coconut water', in IOP Conference Series: Earth and Environmental Science, pp. 1-8. doi: 10.1088/1755-1315/101/1/012010.

Kosseva, M. R. et al. (2017) 'Study on The Bacterial Cellulose Production From Fruit Juices', Bioscience and Biotechnology, 2, pp. 36-42. doi: 10.17501/biotech.2017.2104.

Majesty, J. et al. (2015) Pengaruh Penambahan Sukrosa dan Lama Fermentasi Terhadap Kadar Serat Nata Dari Sari Nanas (Nata de Pina), Jurnal Keteknikan Pertanian Tropis dan Biosistem.

Molina-Ramírez, C. et al. (2017) 'Effect of different carbon sources on bacterial nanocellulose production and structure using the low $\mathrm{pH}$ resistant strain Komagataeibacter medellinensis', Materials. MDPI AG, $10(6$ (639)), pp. 1-13. doi: 10.3390/ma10060639.

Moniri, M. et al. (2017) 'Production and status of bacterial cellulose in biomedical engineering', Nanomaterials, 7(257), pp. 1-26. doi: 10.3390/nano7090257.

Mumbarkar, V. and Shravya, D. (2013) 'Evaluation of Protein Content among Sprouted and Un-Sprouted Seeds of Selected Pulses', Helix, 4, pp. 374-377.
Nazeri, M. A. (2012) Optimization of bacterial cellulose production by using response surface methodology (RSM): the effect of $\mathrm{pH}$, temperature and concentration of fermentation medium.

Neera, Ramana, K. V. and Batra, H. V. (2015) 'Occurrence of Cellulose-Producing Gluconacetobacter spp. in Fruit Samples and Kombucha Tea, and Production of the Biopolymer', Applied Biochemistry and Biotechnology. Humana Press Inc., 176(4), pp. 1162-1173. doi: 10.1007/s12010-015$1637-8$.

Rebelo, A. et al. (2018) 'Dehydration of bacterial cellulose and the water content effects on its viscoelastic and electrochemical properties', Science and Technology of Advanced Materials, 19(1), pp. 203-211. doi: 10.1080/14686996.2018.1430981.

Surma-Ślusarska, B., Presler, S. and Danielewicz, D. (2008) 'Characteristics of Bacterial Cellulose Obtained from Acetobacter Xylinum Culture for Application in Papermaking', Fibres \& Textile in Eastern Europe, $16(4$ (69)), pp. 108-111.

Tsouko, E. et al. (2015) 'Bacterial cellulose production from industrial waste and byproduct streams', International Journal of Molecular Sciences, 16(7), pp. 1483214849. doi: 10.3390/ijms160714832.

Wijayanti, F., Kumalaningsih, S. and Effendi, M. (2012) 'Pengaruh penambahan sukrosa dan asam asetat glacial terhadap kualitas nata dari whey tahu dan substrat air kelapa', Jurnal Industria, 1(2), pp. 86-93.

Yang, J. et al. (2009) 'In situ deposition of platinum nanoparticles on bacterial cellulose membranes and evaluation of PEM fuel cell performance', Electrochimica Acta, 54(26), pp. 6300-6305. doi: 10.1016/J. ELECTACTA.2009.05.073.

Yang, Z. et al. (2012) 'Flexible luminescent $\mathrm{CdSe} /$ bacterial cellulose nanocomoposite membranes', Carbohydrate Polymers, 88(1), pp. 173-178. doi: 10.1016/J. CARBPOL.2011.11.080.

Yustinah, Y. (2012) 'Pengaruh jumlah sukrosa pada pembuatan nata de pina dari sari buah nanas', Jurnal Konversi, 1(1), pp. 29-36. doi: 10.24853/KONVERSI.1.1.\%P.

Zahan, K. ., Hedzir, M. S. . and Mustapha, M. (2017) 'The Potential Use of Papaya Juice as Fermentation Medium for Bacterial Cellulose Production by Acetobacter xylinum 0416', Pertanika J. Trop. Agric. Sci, 40(3), pp. 343-350. 